\title{
SUB-REGIONAL COURTS AND THE RECUSAL ISSUE: EMERGENT PRACTICE OF THE EAST AFRICAN COURT OF JUSTICE
}

\author{
ABIMBOLA A. OLOWOFOYEKU*
}

\section{INTRODUCTION}

The legitimacy of the judicial process is based on the public's respect and on its confidence that the system settles controversies impartially and fairly. Judicial decisions rendered under circumstances that suggest bias, prejudice, or favouritism undermine the integrity of the courts, breed scepticism and mistrust, and thwart the very principles on which the judicial system is based. The judiciary must be extremely diligent in avoiding any appearance of impropriety and must hold itself to exacting standards lest it lose its legitimacy and suffer a loss of public confidence. ${ }^{1}$

Recent developments across common law jurisdictions have attracted attention to the significance of the principles of fair hearing, judicial bias, impartiality and recusal. One of these developments is the overwhelming impact of human rights discourse everywhere. ${ }^{2}$ Another is the growth in regional and sub-regional organisations, often with courts mandated inter alia to review decisions involving human rights claims and/or to embrace human rights values and basic norms

* LLB (Hons) (Lagos), LLM (LSE), PhD (UCL), barrister and solicitor of the Supreme Court of Nigeria, Professor of Law, and Director, Centre for International and Public Law, Brunel University, London. I am grateful to my colleague Professor Ben Chigara, and to Professor John Bell of the University of Cambridge for their comments on earlier drafts of this article.

1 The Supreme Court of Texas in Sun Exploration and Production Co v Jackson (1989) 783 SW 2d 202, 206.

2 D. Galligan and D. Sandler, 'Implementing Human Rights', in S. Halliday and P. Schmidt (eds), Human Rights Brought Home, Hart (2004), pp. 23-56, at 25, write that 'human rights have become a fundamental ideology in modern societies, not only in the West where some levels of effectiveness have been achieved, but in other parts where it is held up as a goal to which to aspire'. M. Svensson, in Debating Human Rights in China, Rowman and Littlefield (2002), p. 28, describes human rights as a 'global language'. Compare I. Balfour and E. Cadava, 'The Claims of Human Rights: An Introduction', 103(2/3) South Atlantic Quarterly (2004): 277-96.

African Journal of International and Comparative Law 20.3 (2012): 365-387

Edinburgh University Press

DOI: 10.3366/ajicl.2012.0041

(C) African Society of International and Comparative Law

www.eupjournals.com/ajicl 
of fair adjudication. One such organisation is the East African Community ${ }^{3}$ (EAC). The current spotlight is on that Community's judicial organ, the East African Court of Justice ${ }^{4}$ (EACJ), which has recently had to grapple with key questions of fundamental justice and fairness. The right to a fair hearing before an independent and impartial tribunal is a standard and prominent feature of rights declarations. ${ }^{5}$ Courts are there to dispense justice, and the process whereby they dispense such justice must itself also be fair and just. The common law's position on this is that justice must not only be done, but must also be seen to be done. ${ }^{6}$ Central to the common law's efforts in this respect is the nemo judex principle, otherwise known as 'rule against bias', which seeks to ensure that the impartiality of the adjudicating tribunal is manifest. While not a human rights court, ${ }^{7}$ the EACJ of necessity recognises and endeavours to apply global rights values, ${ }^{8}$ and established principles of fundamental justice - in particular, the right to a fair hearing and its instrumental rule against bias and recusal law.

Typically, regional and sub-regional courts, when dealing with alleged judicial bias, are reviewing decisions of national courts of member/partner states $e x$ post facto. These kinds of case, while possibly raising important political and sometimes legal issues for a regional organisation, its court and its member states, can often be readily disposed of with the required detachment and objectivity. Matters can, however, be more complicated when the court is faced with alleged bias within its own ranks - particularly if the claim is from a member state. Such situations are rarely provided for in legislation, and thus the court may have to resort to general principles and practice. These may not always be adequate, in which case the court may struggle to develop its own solution. The EACJ recently faced this kind of setting in AG of Kenya v Prof. Anyang' Nyong'o \& others ${ }^{9}$ (Nyong'o).

3 Constituted by the Treaty for the Establishment of the East African Community, as amended on 14 December 2006 and 20 August 2007 ('the EAC Treaty'). The Treaty was signed on 30 November 1999 and came into force on 7 July 2000. The original partner states were Kenya, Uganda and Tanzania. Rwanda and Burundi each became a full member of the Community with effect from 1 July 2007.

4 Established under article 9 of the EAC Treaty.

5 See for example, article 10 of the Universal Declaration of Human Rights; article 6 of the European Convention on Human Rights (ECHR); article 7(1) of the African Charter on Human and Peoples' Rights; cf. article 19 of the Cairo Declaration on Human Rights in Islam.

6 Lord Hewart CJ in $R v$ Sussex Justices ex p McCarthy [1924] 1 KB 256, 259; Lord Bingham of Cornhill in Davidson v Scottish Ministers [2004] UKHL 34, [7]; Frankfurter J, in Public Utilities Comission v Pollak (1952) 343 US 451, 476; the Supreme Court of Canada in Wewaykum Indian Band v Canada [2003] 2 SCR 259; (2003) SCC 45, [65]-[67].

7 See generally, S. T. Ebobrah, 'Litigating Human Rights Before Sub-Regional Courts In Africa: Prospects And Challenges', 17(1) African Journal of International and Comparative Law (2009): 79-101; S. T. Ebobrah, 'Human Rights Developments in African Sub-regional Economic Communities during 2010', 11(1) African Human Rights Law Journal (2011): 216-50.

8 The EAC partner states undertook under article 7(2) of the EAC Treaty to abide (inter alia) by the rule of law, and 'universally accepted standards of human rights'. The 'fundamental principles' of the EAC also include the 'promotion and protection of human and peoples' rights in accordance with the provisions of the African Charter on Human and Peoples' Rights' (see article 6(d) of the EAC Treaty).

9 EACJ, application no. 5 of 2007, decided 6 February 2007; [2007] EACJ 1. 
This article examines critically the emerging recusal jurisprudence of the EACJ to questions of judicial bias, against the backdrop of its landmark decision in Nyong'o. From a detailed analysis of the decision and of the Court's preferred modus operandi, it emerges that neither the EAC Treaty nor the common law provide satisfactory solutions for the EACJ. The Court's reliance on certain pronouncements of the Constitutional Court of South Africa is also problematic. The conclusion is that amendments to the EAC Treaty would be required in order to address properly the deficiencies in the Court's emergent jurisprudence on judicial bias.

\section{JUDICIAL BIAS AND RECUSALS}

The authority of any judicial system is highly dependent upon trust. In the field of judicial bias and recusals, this notion of trust is embraced within the concept of 'confidence'. The importance of trust in this context has been widely recognised and accepted by both ancient and modern judges. The quotation at the beginning of this article from the decision of the Supreme Court of Texas is one modern example. Similarly, Lord Bingham said in Davidson v Scottish Ministers: ${ }^{10}$

It has ... been accepted for many years that justice must not only be done but must also be seen to be done. In maintaining the confidence of the parties and the public in the integrity of the judicial process it is necessary that judicial tribunals should be independent and impartial and also that they should appear to be so.

Lord Denning MR, with his typical clarity and compressed reasoning, expressed the principle in these words: 'Justice must be rooted in confidence: and confidence is destroyed when right-minded people go away thinking: "The judge was biased." ${ }_{11}$ This trust principle is crucial enough in domestic legal systems. It, however, assumes greater magnitude in a supra-national setting where nationals of states may not be so familiar with the reputations of judges from other states, or may otherwise be naturally inclined to view foreign judges with suspicion. Regional and sub-regional organisations are often established to promote cohesion, cooperation and/or integration between the participating states. There is often also an underlying desire to prevent violent conflict. It is therefore of the utmost importance for the judicial organs of these organisations to command the trust and confidence of all the member states. Failure to achieve this may render impossible the goals of peaceful resolution of supra-national disputes within the region. This brings into sharper focus the issue of public perceptions of decision making in regional and sub-regional tribunals like the EACJ, and the need for such courts to tread the path of judicial impartiality with great caution. An essential part of this process is to articulate clearly the principles upon which the

10 [2004] UKHL 34, paragraph 7. Compare Frankfurter J, in Public Utilities Comission v Pollak 343 US 451, 476 (SC, 1952).

11 Metropolitan Properties Ltd v Lannon [1969] 1 QB 577, 599. 
tribunal aims to implement the norms of fundamental justice and fair and impartial adjudication on which it seeks to rely. Needless to say, it is also vital that such principles are robust and beyond reproach.

The demand for the manifest fairness and impartiality of those who adjudicate on disputes by the rule of law and the fundamental principles of justice is both instrumental and an end in itself. It is instrumental in engendering the confidence in the administration of justice without which peaceful resolutions of disputes would be impossible. It is also an end in ensuring that procedural fairness is in fact achieved, and that litigants in fact receive a fair hearing.

The rule against bias is how the common law effectuates these ideals. In a statement that aptly encapsulates the common law principle, the Lord JusticeClerk said in Robbie The Pict v Her Majesty's Advocate ${ }^{12}$

A judge who considers that there is a sound objection to his participation in a case has a duty to recuse himself at once. If he is in doubt, he should disclose his difficulty to the parties. But if he considers that there is no sound objection to his participation, it is his plain duty to proceed with the case...

This simply means that judges who are embarrassed or compromised by 'interest' or 'favour' must recuse themselves or else be thereafter disqualified. At the very least, a judge should resolve all doubts about potentially disqualifying factors in favour of disclosure of his or her difficulty to the parties. As far as embarrassing or compromising factors go, when the issue relates to financial interests, the situation is relatively straightforward. A judge with a direct financial interest in the outcome of a case is 'automatically' disqualified, and must recuse himself or herself. ${ }^{13}$ This was originally an immutable principle, such that any direct financial interest, 'however small', ${ }^{14}$ attracted disqualification. However, de minimis financial interests may now be ignored, ${ }^{15}$ as may situations in which the decision could not realistically affect the judge's interests. ${ }^{16} \mathrm{~A}$ judge who is a party to the dispute or who is otherwise personally interested in its subject matter may also be automatically disqualified. ${ }^{17}$ Controversially, in an unfortunate House

12 [2002] Scot HC 333, [16].

13 Hesketh v Braddock (1766) 3 Burr 1847, 97 ER 1130; Dimes v Grand Junction Canal (1852) 3 HLC 758, 10 ER 301; $R$ v Lowe, ex p Peterson [1912] St R Qd 138 (FC); Re Ritchie (1993) 8 WAR 469 (SC, WA); Webb v R (1994) 181 CLR 41 (HCA, Deane J at 75); Ebner v Official Trustee in Bankruptcy [1999] FCA 110, Full Court, Federal Court; Cook v Patterson [1971] NZLR 861 (NZ CA: Turner P at 862-3); Anderton v Auckland City Council [1978] 1 NZLR 657 (Mahon J); Auckland Casino Ltd v Casino Control Authority [1995] 1 NZLR 142 (NZ CA: Cooke P at 148-9).

14 See Blackburn J in $R v$ Rand (1866) LR 1 QB 230, 232; Slade $\mathrm{J}$ in $R v$ Camborne Justices ex $p$ Pearce [1955] 1 QB 41, 47.

15 Locabail (UK) Ltd v Bayfield Properties [2000] 1 All ER 65, 71; Cooke P in Auckland Casino Ltd $v$ Casino Control Authority [1995] 1 NZLR 142, 148.

16 Locabail (UK) Ltd v Bayfield Properties [1999] EWCA Civ 3004, [8]; the Supreme Court of New South Wales in Dovade Pty Ltd v Westpac Banking Group (1999) 46 NSWLR 168, 186-7.

17 The Earl of Derby's case (1613) 12 Co. Rep. 114, 77 ER 1390; Brookes $v$ The Earl of Rivers (1668) Hard 503, 145 ER 569; Wright v Crump (1702) 2 Ld Raym 767, 92 ER 12. 
of Lords extension to the automatic disqualification principle, a judge may also be 'automatically' disqualified for 'other relevant interests'. ${ }^{18}$ However, the recent trend is to narrow down the scope of automatic disqualification and to adopt a very restrictive approach to it. ${ }^{19}$

Where the alleged disqualifying factor does relate not to the judge's interests, but, rather, to some other factor (such as alleged association with or ill-will towards a party, witness, counsel, and so on), matters are not so straightforward. A judge who considers that there is no sound objection against their sitting must continue to sit. The difficulty with such a simple-sounding doctrine is that the question whether there is a sound objection is objective. The objective standard means that, (that is, in the view of a reasonable third party, also known as the 'informed observer'), there is (in English law) a 'real possibility' of bias, ${ }^{20}$ or (in other parts of the Commonwealth) a 'reasonable apprehension' or 'reasonable suspicion' of bias, ${ }^{21}$ or (in US Federal law) a situation wherein the judge's impartiality 'might reasonably be questioned'. ${ }^{22}$

Beyond the common law, the requirement for independent and impartial adjudication is also a global norm. The increase in the number and reach of international tribunals means that this norm must also find its expression in the international judicial sphere-and so it does. As indicated earlier, rights declarations invariably contain 'due process' or 'fair hearing' before an 'impartial tribunal' clause. I will give just a few examples. Article 6(1) of the European Convention on Human Rights provides that 'In the determination of his civil rights and obligations or of any criminal charge against him, everyone is entitled to a fair and public hearing within a reasonable time by an independent and impartial tribunal established by law.' ${ }^{23}$ Article 7(1) of the African Charter on Human and

$18 R v$ Bow Street Metropolitan Stipendiary Magistrate, ex p Pinochet Ugarte (No. 2) [1999] UKHL $1 ;$ [2000] 1 AC 119.

19 See generally, Locabail, supra notes 15 and 16. Also $R$ v Mulvihill [1990] 1 All ER 436 (CA); BTR Industries South Africa (Pty) Ltd v Metal and Allied Workers Union [1993] SA 673; Clenae Pty Ltd v ANZ Banking Group [1999] VSCA 35; Dovade Pty Ltd v Westpac Banking Group [1999] 46 NSWLR 168; $R$ v Industrial Court [1966] Qd R 245; Auckland Casino Ltd v Casino Control Authority [1995] 1 NZLR 142.

20 See Porter v Magill [2002] 2 AC 357; In re Medicaments and Related Classes of Goods (No. 2) [2001] 1 WLR 700; Lawal v Northern Spirit Limited [2003] UKHL 35; Davidson v Scottish Ministers [2004] UKHL 34. The test originally referred to a 'real danger of bias' ( $R v$ Gough [1993] AC 646). Porter v Magill modified it, bringing UK law into line with the jurisprudence of the European Court of Human Rights.

21 See e.g. $R v$ Webb [1994] HCA 30, (1994) 181 CLR 41 (HC, Australia); Cook v Patterson [1972] NZLR 861 (CA, New Zealand); EH Cochrane Ltd v Ministry of Transport [1987] 1 NZLR 146 (CA, New Zealand); Auckland Casino Ltd. v Casino Control Authority [1995] 1 NZLR 142 (CA, New Zealand); Committee for Justice and Liberty v National Energy Board (1976) 68 DLR (3d) 716 (SC, Canada); $R v S$ (RD) (1997) 151 DLR (4th) 193 (SC, Canada); SACCAWU v Irvin \& Johnson [2000] 8 B Const LR 886, 2000 (3) SA 705 (Const Ct, South Africa); President of the Republic of South Africa and others $v$ South African Rugby Football Union and others [1999] 7 B Const LR 725, 1999 (4) SA, 147 (Const Ct, South Africa).

2228 USC section 455(a); United States v Cooley (1993) 1 F 3d 985, 993 (10th Circ); Liteky v US (1994) 127 L Ed 2d 474, 486; Liljeberg v Health Services Acquisition Corp. (1988) 486 US 847; Microsoft Corp. v US (2000) 147 L Ed 2d 1048, 1049.

23 For similar provisions, see article 14(1) of the International Covenant on Civil and Political Rights, article 10 of the Universal Declaration of Human Rights. 
Peoples' Rights similarly provides: 'Every individual shall have the right to have his cause heard. This comprises... (d) the right to be tried within a reasonable time by an impartial court or tribunal. ${ }^{24}$ Apart from the various rights declarations, international recognition of this global norm is also manifested in judicial oaths. ${ }^{25}$

The European Court of Human Rights (ECtHR) has a well-developed jurisprudence on article 6(1) of the Convention, developed mainly in the context of the Court being asked to rule on alleged judicial bias in national courts. ${ }^{26}$ As with the common law, the standard adopted by the Court is objective, with the Court explaining in Hauschildt v Denmark ${ }^{27}$ that

Under the objective test, it must be determined whether, quite apart from the judge's personal conduct, there are ascertainable facts which may raise doubts as to his impartiality. In this respect even appearances may be of a certain importance. What is at stake is the confidence which the courts in a democratic society must inspire in the public and above all, as far as criminal proceedings are concerned, in the accused. Accordingly, any judge in respect of whom there is a legitimate reason to fear a lack of impartiality must withdraw.

As has been seen above, 'slight modifications' of the applicable common law principles have brought the UK's recusal law into line with the jurisprudence of the ECtHR. The International Criminal Tribunal for the former Yugoslavia (ICTY) has also embraced the relevant jurisprudence of the ECtHR. In Prosecutor $v$ Furundzija $a^{28}$ the Appeals Chamber of the ICTY conducted an extensive review of the principles applicable both in common law and civil law jurisdictions, and by the ECtHR, and came to the following conclusions: ${ }^{29}$

Having consulted this jurisprudence, the Appeals Chamber finds that there is a general rule that a Judge should not only be subjectively free from bias, but also that there should be nothing in the surrounding circumstances which objectively gives rise to an appearance of bias. On this basis, the Appeals Chamber considers that the following

24 On this, see generally F. Ouguergouz, The African Charter on Human and Peoples' Rights, Martinus Nijhoff (2003), pp. 132-52; F. Viljoen, International Human Rights in Africa, Oxford University Press (2007), 238-9; B. Manby, 'Civil and Political Rights in the African Charter on Human and Peoples' Rights', in M. Evans and R. Murray (eds), The African Charter on Human and Peoples' Rights, 2nd edn, Cambridge University Press (2008), 198-206.

25 See for example, article 5 of the SADC Protocol on Tribunal and the Rules of Procedure Thereof ('the SADC Protocol'); article 3 of the Rules of the Court of Justice of the Economic Community of West African States; article 11 of the Statute of The International Tribunal for The Law of The Sea; Rule 14 of the Rules of Procedure and Evidence of the International Criminal Tribunal for the former Yugoslavia (ICTY).

26 See, e.g., Delcourt v Belgium (1970) 1 EHRR 355; De Cubber v Belgium (1984) 7 EHRR 236; Hauschildt v Denmark (1989) 12 EHRR 266; Kyprianou v Cyprus (2007) 44 EHRR 27, [2005] ECHR 873.

27 (1989) 12 EHRR 266, [48] (referring to De Cubber v Belgium, above).

28 Case no. IT-95-17/1-A, 21 July 2000.

29 At [189]. 
principles should direct it in interpreting and applying the impartiality requirement of the Statute:

A. A Judge is not impartial if it is shown that actual bias exists.

B. There is an unacceptable appearance of bias if:

i) a Judge is a party to the case, or has a financial or proprietary interest in the outcome of a case, or if the Judge's decision will lead to the promotion of a cause in which he or she is involved, together with one of the parties. Under these circumstances, a Judge's disqualification from the case is automatic; or

ii) the circumstances would lead a reasonable observer, properly informed, to reasonably apprehend bias.

The African Commission on Human and Peoples' Rights also applies this objective test, also referring with approval to the ECtHR's jurisprudence. ${ }^{30}$ In INTERIGHTS and others $v$ Mauritania, ${ }^{31}$ the Commission noted that it 'important to take into consideration the public perception or adopt the principle of a reasonable person in the consideration of a communication'. The question, according to the Commission, is "Would the public or a reasonable man believe that a member of the Commission would "take part" in the deliberation of a communication concerning his country and take a neutral decision? ${ }^{32}$ In this case the Commission affirmed that it 'adheres strictly to the natural justice principle of nemo judex in sua causa', stating that it is 'very critical in the administration of justice, for justice must not only be done, but must be seen to be done'. ${ }^{33}$ The principle has also been affirmed by the Commission in the context of the fair hearing and impartiality provisions of article 7(1) (d) of the African Charter. ${ }^{34}$ In this respect, the Commission is clear that an appearance or impression of a lack of impartiality would constitute a violation of article 7(1) (d) ${ }^{35}$

Against the background of this great cloud of witnesses, I will now examine the emerging recusal jurisprudence of the EACJ, as seen in Nyong'o.

\section{THE NYONG'O DECISION}

In AG of Kenya v Prof. Anyang' Nyong'o \& others $^{36}$ the Applicant (the Attorney General of Kenya) applied for two of the judges of the EACJ (Moijo Ole Keiwua

30 See for example Communication 281/03, Marcel Wetsh'okonda Koso and others $v$ DRC, [80]-[81].

31 Communication 373/09.

32 At [50].

33 At [51].

34 See for example, Marcel Wetsh'okonda Koso, supra note 30, at [79].

35 Communications 222/98-229/99, Law Office of Ghazi Suleiman v Sudan, [67]; Communications 48/90-50/91-52/91-89/93, Amnesty International and others v Sudan, [68].

36 Keiwua P, Mulenga VP, Ramadhani, Mulwa and Nsekela JJ. 
P, President of the Court (a Kenyan judge), and Kasanga Mulwa J (another Kenyan judge)) to recuse themselves from a case before the Court, and for the Court to set aside one of its own decisions, delivered in 2006, because those two judges had participated in that decision while allegedly disqualified on grounds of bias.

The applicant initially endeavoured to invoke both the 'interest' and 'favour' principles. The two impugned judges were allegedly 'automatically disqualified' from hearing both the earlier case and the current case, of which the Attorney General of Kenya was a party, because in 2003, Keiwua P had been suspended from the performance of his functions of a Judge of Appeal in Kenya, and, a tribunal had been appointed in Kenya to investigate both judges. The two judges had 'failed to disclose their interests', which was 'a material fact', namely, the fact that they were related to the Republic of Kenya in a manner that rendered it impossible for them to give a fair hearing to the Attorney General of Kenya. Invoking the trust principle discussed above, it was claimed that the failure of the judges to disclose their interests and recuse themselves had allegedly adversely affected the integrity of the Court and undermined the confidence of East Africans in the Court. ${ }^{37}$

The EACJ eventually dismissed the application, holding that, in the circumstances, neither judge had been under a duty of disclosure, and neither was disqualified from participating in the present or previous proceedings. The decision afforded the EACJ a golden opportunity to develop and refine its own recusal law while avoiding the difficulties of the prevailing common law discourse. The case raises a number of persistent questions about recusal law, which will be explored in this article-waiver, the principle of automatic disqualification as extended in the Pinochet $^{38}$ case, and some procedural and jurisdictional issues.

On the question of its jurisdiction to hear an application for it to set aside its own judgement on grounds of bias, the EACJ noted ${ }^{39}$ that, since it had not been seriously argued that it lacked such jurisdiction, it was not necessary to go into that issue in detail. However, it still felt it necessary to pronounce on the question, saying: ${ }^{40}$

It suffices to say that only through strict adherence to the principle of judicial impartiality can protection of the universally accepted right of every litigant to a fair trial, be enforced. We think that apart from inherent jurisdiction at common law, in appropriate circumstances,

37 The allegation that the confidence of East Africans had been undermined was later withdrawn. The application against Kulwa J was also later withdrawn when the Attorney General of Kenya was confronted with publications in Kenya's Official Gazette that indicated that the judge's name had been deleted from the list of judges who were to be investigated, had been granted early retirement with full benefits and had been offered good wishes by the Kenyan President on his appointment to the EACJ. The claim that the judges were automatically disqualified was also withdrawn.

$38 R v$ Bow Street Metropolitan Stipendiary Magistrate, ex p Pinochet Ugarte (No. 2) [1999] UKHL 1 [2000] 1 AC 119.

39 At p. 13 of its ruling.

40 Ibid. 
this Court can invoke its jurisdiction under Article 35 of the Treaty ${ }^{41}$ to review its order as unjust if the order was made in violation of the principle.

With regard to the substantive issue of disqualification for bias, the Court noted that 'Judicial impartiality is the bedrock of every civilized and democratic judicial system', requiring judges to adjudicate disputes 'impartially, without bias in favour of or against any party to the dispute'. ${ }^{42}$ In this context, the Court referred to article 24 of the Treaty ${ }^{43}$ and the judicial oath taken by the Justices of the Court, whereby they undertake to do justice 'without fear or favour, affection or ill will'.

On the applicable law, the Court stated that, "where it is established that the judge is a party to the cause or has a relevant interest in its subject matter and outcome, the judge is automatically disqualified from hearing the cause', ${ }^{44}$ apparently endorsing the dubious Pinochet extension of the automatic disqualification principle. Although the applicant had initially attempted to trigger automatic disqualification by claiming that the judges had 'interests' in the matter, he rightly abandoned that claim (which was clearly untenable), and it is unfortunate that the Court still proceeded to make this (arguably obiter) statement. The Pinochet extension to automatic disqualification has hardly found favour anywhere-and rightly so. The EACJ should distance itself from it, unless the Court, by the phrase 'a relevant interest' meant 'a direct and substantial financial interest'.

Apart from these situations of 'automatic' disqualification,

[A] judge is only disqualified if there is likelihood or apprehension of bias arising from such circumstances as relationship with one party or preconceived views on the subject matter in dispute. The disqualification is not presumed like in the case of automatic disqualification. The applicant must establish that bias is not a mere figment of his imagination. ${ }^{45}$

The Court accepted that the test of 'reasonable apprehension of bias' is good law, the relevant question being whether 'the circumstances give rise to a reasonable apprehension, in the view of a reasonable, fair-minded and informed

41 Article 35(3) of the EAC Treaty provides: 'An application for review of a judgment may be made to the Court only if it is based upon the discovery of some fact which by its nature might have had a decisive influence on the judgment if it had been known to the Court at the time the judgment was given, but which fact, at that time, was unknown to both the Court and the party making the application, and which could not, with reasonable diligence, have been discovered by that party before the judgment was made, or on account of some mistake, fraud or error on the face of the record or because an injustice has been done.'

42 At pp. 15-16.

43 'Judges of the Court shall be appointed by the Summit from among persons recommended by the Partner States who are of proven integrity, impartiality and independence.'

44 At p. 17.

45 Ibid. 
member of the public, that the judge did not (will not) apply his mind to the case impartially'. ${ }^{46}$

On the issue of the failure of Keiwua $\mathrm{P}$ to make disclosure to the parties at the start of the hearing of the impugned 2006 petition, the Court noted that the applicant had not specified what the judge had been under a duty to disclose. The Court proceeded to narrow the possibilities down to the statement in the applicant's pleadings referring to the 'facts that he was suspended from performance of functions of Judge of Appeal and that a tribunal was appointed to investigate allegations that he was involved in corruption, unethical practice, and absence of integrity' and concluded that Keiwua $\mathrm{P}$ was under no obligation to disclose these facts. The Court stated ${ }^{47}$

A judicial officer is required to disclose facts that may raise apprehension of possible bias on his part, in order to show that he has no actual bias and to give opportunity to a party who considers that he might be prejudiced, to exercise the right to apply for the judge to recuse himself or to waive that right.

The Court rightly rejected the applicant's contention that disclosure is for public consumption in order to retain its confidence in the judiciary. According to it, disclosure is not a pre-condition for the application to be made, and a litigant who has knowledge of disqualifying facts is free to apply for recusal even in absence of their disclosure by the judge. This meant that an applicant 'who relies on the judge's failure to disclose material facts must show that those facts were not within his or his legal advisor's knowledge'.

Furthermore, the Court said that 'failure of a judge to disclose facts that are within public knowledge cannot be a ground on which a reasonable member of public would apprehend bias'. ${ }^{48}$ According to the Court, as it had been a matter of public knowledge since 2003 that Keiwua P had been suspended and had been the subject of an investigation by a tribunal of acts undertaken by the Kenyan government, of which the applicant had been the principal legal advisor, it was reasonable to conclude that the applicant had been consulted on those matters - and, in any case, there had been no suggestion that these matters were not within his knowledge. ${ }^{49}$ This led the Court to conclude that, if those facts had in any way generated an apprehension of bias on Keiwua P's part, then the Attorney General would have been entitled to object to his sitting when the case originally came up for hearing on 24 November 2006. Therefore, '[h]is omission to do so leads to only two possible inferences. Either he opted to waive his right to object or he did not harbour the apprehension or think that a reasonable, fair-minded and informed member of the public would perceive such apprehension.'

The Court rejected the applicant's claims that he had not waived his rights to object to the allegedly disqualifying factors, and that he had therefore not lost his

46 At p. 18.

47 At p. 19.

48 Ibid.

49 At p. 20. 
right to raise the objection at a later stage. The Court noted that 'a litigant seeking disqualification of a judge from sitting on the ground of appearance of bias must raise the objection at the earliest opportunity' and highlighted the failure of the applicant to provide any explanation for his omission to raise objections during the 2006 application.

On the issue of apprehensions of bias, the applicant's argument in this respect was that members of the public would have been concerned that, 'as a human being the judge would harbour animosity against the Government that suspended him from his duty and subjected him to the resultant disadvantages and would seek "to hit back" by deciding the case against the Government of Kenya represented by the applicant'. ${ }^{50}$ The opposing arguments included a claim that a reasonable member of the public would not think in this way, but was more likely to think that 'judges on suspension would want to ingratiate themselves with the Government in order to get reprieve'. ${ }^{51}$ The Court's response was thus:

[A] reasonable person would not perceive that a judge, whose conduct is under investigation, would risk conducting an unfair adjudication against the very authority investigating his conduct. A reasonable and informed person, knowing that the judge sits in a panel of five judges, trained and sworn to administer justice impartially, would not in our view, perceive that the judge would [scheme] to single handedly deny the applicant a fair hearing or justice. We think a reasonable, informed and fair-minded member of the public, appreciating the subject matter and nature of the reference, would credit the judge with sufficient intelligence not to indulge in futile animosity. ${ }^{52}$

With regard to the application that Keiwua $\mathrm{P}$ recuse himself from the present proceedings, the Court noted ${ }^{53}$ that the judge had declined to do so, that the Court agreed with his position 'as there was no basis' for the application, and that his response should be deemed to have been incorporated into the Court's own decision.

\section{A NASCENT RECUSAL JURISPRUDENCE ANALYSED}

The EACJ's substantive decision revolved around two main points - waiver, and the perceptions of a fair-minded and informed observer (described as 'the putative observer' by Lord Clarke in AG of the Cayman Islands v Tibbetts ${ }^{54}$ ). However, as has been said, the decision also raises a number of other issues (particularly, jurisdiction and process), which will be examined. I will start with waiver. 


\section{A. Waiver}

As seen above, the EACJ in the Nyong'o case seemed to take as accepted the proposition that a party can waive disqualifying factors, and proceeded to apply the waiver principle. This principle has been recognised in the international sphere. For example, the Appeals Chamber of the ICTY accepted it in Prosecutor $v$ Furundzija,${ }^{55}$ and, as shall presently appear, the ECtHR also recognises it.

Nevertheless, the whole notion of waiver in bias cases is controversial. While the Appeals Chamber of the ICTY was prepared to recognise it in Prosecutor $v$ Furundzija ${ }^{56}$ the Tribunal also stated that its observations in that respect 'should not be construed as relieving an individual Judge of his or her duty to withdraw from a particular case if he or she believes that his or her impartiality is in question'. In US Federal law, 28 USC § 455(e) actually prevents a judge from accepting a waiver of any ground for disqualification enumerated in $\S 455(\mathrm{~b})$, which lists a number of disqualifying factors, mostly relating to actual bias or disqualifying interests. ${ }^{57} 28$ USC provides for waiver in cases of apprehended bias - but on the condition that any such waiver is preceded by full disclosure on the record of the basis for disqualification. ${ }^{58}$ The ECtHR similarly takes the position that waivers in respect of the right to a fair hearing by an impartial tribunal under article 6 of the European Convention on Human Rights (ECHR) must be informed, voluntary and unequivocal. ${ }^{59}$ This is a 'rigorous' requirement. ${ }^{60}$ Lord Bingham said in Millar v Procurator Fiscal ${ }^{61}$ that 'unequivocal' in this context means 'clear and unqualified'. Additionally, according to Sir John Romilly MR in Vyvyan $v$ Vyvyan $^{62}$ '[w]aiver or acquiescence, like election, presupposes that the person to be bound is fully cognizant of his rights, and that, being so, he neglects to enforce them, or chooses one benefit instead of another, either, but not both, of which he might claim.' Finally, in Locabail (UK) Ltd v Bayfield Properties, ${ }^{63}$ the Court of Appeal in England said that 'a party with an irresistible right to object to a judge hearing or continuing to hear a case may ... waive his right to object. It is

55 Case no. IT-95-17/1-A, 21 July 2000, [174].

56 At [175].

57 For example, where he has a personal bias or prejudice concerning a party, personal knowledge of disputed evidentiary facts concerning the proceeding, or has served as lawyer or witness or government adviser in the matter in controversy, or he or his spouse/minor child has a financial interest in the matter, or is a party or officer of a party, or lawyer or witness or has an interest that could be substantially affected by the outcome, and so on.

5828 USC section 455(e). Compare Lord Browne-Wilkinson in $R v$ Bow Street Magistrate, ex parte Pinochet (No. 2) [2000] 1 AC 119, 137 -the waiving party must have 'acted freely and in full knowledge of the facts'. See also the detailed guidance laid down by the Court of Appeal in Jones v DAS Legal Expenses Insurance Co [2003] EWCA Civ 1071, [35]; Peter Smith v Kvaerner Cementation Foundations Ltd [2006] EWCA Civ 242, [29].

59 Deweer v Belgium (1980) 2 EHRR 439; Håkansson and Sturesson v Sweden (1990) 13 EHRR 1; Pfeifer and Plankl v Austria (1992) 14 EHRR 692; McGonnell v United Kingdom (2000) 30 EHRR 289.

60 Lord Hope in Millar v Procurator Fiscal [2001] UKPC D 4, [54].

61 [2001] UKPC D 4, [31].

62 (1861) 30 Beav 65, 74; 54 ER 813, 817.

63 [1999] EWCA Civ 3004, [15]. 
however clear that any waiver must be clear and unequivocal, and made with full knowledge of all the facts relevant to the decision whether to waive or not.'

The corollary to these principles is the principle that litigants must not hide 'jokers' up their sleeves. Toohey J of the High Court of Australia brought both principles together in Vakauta $v$ Kelly. ${ }^{64}$ He stated that there is no reason why a litigant who is fully aware of the circumstances from which bias might be inferred should not be able to waive his right to object, and added that "when a party is in a position to object but takes no steps to do so, that party cannot be heard to complain later that the judge was biased'. Brennan, Deane and Gaudron JJ said in the same case that '[b]y standing by, such a party has waived the right subsequently to object. ${ }^{65}$ In England, Sedley LJ put it in these words: 'appellate and reviewing courts tend not to look favourably on complaints of vitiating bias made only after the complainant has taken his chance on the outcome and found it unwelcome'. ${ }^{66}$ The Appeals Chamber of the ICTY certainly seemed to reflect this in Prosecutor v Furundzija, ${ }^{67}$ saying

The Appeals Chamber considers that it would not be unduly burdensome for the Appellant to find out the qualifications of the Presiding Judge of his trial. He could have raised the matter, if he considered it relevant, before the Trial Chamber, either pre-trial or during trial.

Not having raised any earlier objections, the Tribunal was not impressed with the appellant's claims that he had only become aware of the alleged disqualifying factors after judgement had been delivered, and decided that the appellant could be said to have waived his right to object.

On the other hand, Callinan J of the High Court of Australia alluded in Johnson $v$ Johnson ${ }^{68}$ to possible concerns with waivers, especially in respect of final courts such as the High Court of Australia, whose decisions, as those of a final court, "may have the capacity to affect the rights and obligations of non-parties, who, if given the opportunity might have been unprepared to offer to waive', ${ }^{69}$ while Lord Hope took the view in Millar $v$ Procurator Fiscal ${ }^{70}$ that the legal system 'would be unduly hampered if the right to a public hearing by an independent and impartial tribunal were to be incapable in any case of being waived'. This is consistent with the approach of the ECtHR which recognises that the fair hearing rights under article 6 of the ECHR can be waived if the waiver is informed, voluntary and unequivocal. ${ }^{71}$ This allegedly 'rigorous' requirement, however, has not prevented

64 (1989) 167 CLR 568, 587; cf. Locabail [1999] EWCA Civ 3004, [26].

65 (1989) 167 CLR 568, 572.

66 Steadman-Byrne v Amjad [2007] EWCA Civ 625, [17].

67 Case no. IT-95-17/1-A, 21 July 2000, [174].

68 [2000] HCA 48, [78]-[79].

69 Callinan J repeated his reservations in Ebner v Official Trustee [2000] HCA 63, [184].

70 [2001] UKPC D 4, [53].

71 In Håkansson and Sturesson v Sweden (1990) 13 EHRR 1, [66], the Court recognised that waiver may be 'tacit', but, significantly, also said that any waiver 'must not run counter to any important public interest'. I will return later to the latter point. 
the court from implying waiver in a case in which the party was fully aware of the alleged disqualifying factors, but chose not to object. ${ }^{72}$

It seems clear that the principle of waiver was (if acceptable) rightly applied by the EACJ in Nyong'o. Clearly, the facts that allegedly disqualified Keiwua P were well known to the Government of Kenya and its Attorney General long before the proceedings in the first hearing began, and, having failed to raise any objection during those proceedings, it would seem obvious that any right to objection had thereby been waived. Nevertheless, the reservations expressed by Callinan $\mathrm{J}$ in Johnson v Johnson and Ebner v Official Trustee should not be lightly dismissed. The Nyong'o case was archetypal of Callinan J's reservations. The case itself concerned the legality of the process of 'electing' the nine members of the East African Legislative Assembly (EALA) to represent the Republic of Kenya, and the rules under which the process was undertaken. The argument was that the provisions of article 50 of the EAC Treaty had been violated by the Kenyan electoral process. Thus, the outcome of the case had the potential to affect the whole EAC. Furthermore, any decision in the case would affect the interests of those who had been elected under the Kenyan process, and the competitors for their seats. These parties may not have been inclined to waive any disqualifying factor, and would not necessarily have accepted the Attorney General of Kenya's waiver on their behalf. Also relevant is the statement of the ECtHR in Håkansson and Sturesson v Sweden ${ }^{73}$ that any waiver 'must not run counter to any important public interest'. It is arguable that there is an important public interest in the due election of members of the EALA, seeing that decisions taken in the Assembly have the potential to affect every citizen in every partner state of the Community. Therefore, accepting a waiver of a disqualifying factor in a case challenging the election of members of the EALA would be counter to that important public interest.

While it is clear that a blanket ban on acceptance of waivers would be counterproductive, it is submitted that the Court should, at the very least, consider explicitly, in each case in which a waiver is put forward, the question whether there are any important public interests that would militate against accepting the waiver. In the Nyong' $o$ case, the EACJ did not do this, and it is not clear what the outcome would have been if it had.

The statement of the Appeals Chamber of the ICTY in Prosecutor $v$ Furundzija ${ }^{74}$ that its observations on waiver 'should not be construed as relieving an individual Judge of his or her duty to withdraw from a particular case if he or she believes that his or her impartiality is in question' is also pertinent. No judicial tribunal should hide behind technicalities to shield inappropriate decisions by judges to continue to sit in situations wherein they would normally be expected to recuse themselves. The principle of waiver, while a possibly useful defensive tool in appropriate cases to prevent cynical tactical manoeuvres by litigants, should 
never be employed as a sword in cases of judicial bias. It is also questionable whether constructive (as opposed to explicit) waiver should be permitted at all. It is significant that the International Bar Association (IBA) Guidelines on Conflicts of Interest in International Arbitration provide for a 'non-waivable red list' of disqualifying factors, encompassing situations wherein the disqualifying factor cannot be cured by disclosure. ${ }^{75}$ That certain disqualifying factors can be considered non-waivable by US Federal Law and by the IBA Guidelines should perhaps sound a note of caution and move one to pause for thought. Waiver is controversial, raises difficult questions, and should, if used at all, be used very sparingly, and perhaps only in cases of clear and obvious abuse of the Court's process.

It may of course be argued that article 35 of the EAC Treaty is decisive on the question of waiver and the jurisdiction to review past decisions, since article 35(3) partly restricts the basis of review to discovery of new material facts after judgement had been delivered. The better view appears to be that article 35(3) is more an issue of a statutory limitation to the right of review than an issue of waiver. Article 35(3) may well present an insurmountable obstacle in the path of an applicant for review who had been aware of disqualifying facts, but chose not to object at the time. If so, this would render the question of waiver in respect of post-judgement applications for review a non-issue. Considering that such a construction of article 35(3) would have delivered a swift and fatal blow to the application to vacate the EACJ's 2006 decision, it is remarkable that neither the Court nor counsel raised the point.

\section{B. The fair-minded observer}

The competing contentions before the EACJ in Nyong' $o$ about what a fair-minded and informed observer would perceive have been referred to above. The Court dealt with this issue in a fairly orthodox common law way. It considered the arguments and counter-arguments concerning the state of mind of this fictional character, and then pronounced its own conclusion. There are a number of problems with the orthodox approach. These have been well aired elsewhere ${ }^{76}$ and need not be re-hashed here. It suffices to say that it is unedifying for judges and counsel to become bogged down in speculations about what a hypothetical fair-minded observer would think about alleged disqualifying facts. However, this is the generally accepted common law principle. How would that apply here? The arguments by the applicant's counsel were tenable, and might well match the thoughts of some reasonable people, East African or otherwise. The opposing arguments were also tenable, as were the Court's own rationalisations. It would therefore be unconvincing and artificial to attribute only one of those views to a

75 See Part II, Paragraph 1, of the IBA Standards ('Practical Application of the General Standards'). The Standards also provide for a 'waivable red list', 'orange' list and 'green' list. The last one lists situations that do not call for disclosure.

76 A. Olowofoyeku, 'Bias and the Informed Observer: A Call for a Return to Gough', 68(2) Cambridge Law Journal (2009): 388-409. 
reasonable and fair-minded observer. Each of those positions is capable of being taken by a reasonable and fair-minded observer. It has been argued elsewhere ${ }^{77}$ that matters ought to be returned to what was stated by Lord Goff in $R v$ Gough ${ }^{78}$

I think it unnecessary, in formulating the appropriate test, to require that the court should look at the matter through the eyes of a reasonable man, because the court in cases such as these personifies the reasonable man; and in any event the court has first to ascertain the relevant circumstances from the available evidence.

Nyong'o presented the EACJ with an opportunity to distance itself from the questionable common law position on the issue and to dispense with the artificial construct that has been superimposed on the common law. Unfortunately, the EACJ adhered to the common law fiction that it was assessing determinatively what a reasonable observer would think. In truth (as in every other case on the matter, the Court was merely making a determination of what it (as a group of reasonable, fair-minded and well-informed people) thought. ${ }^{79}$ It stands to reason, therefore, that it is futile to embark on a discussion of whether the Court was 'right' in its conclusion that a reasonable observer would not have apprehended bias on the part of Keiwua P. It is submitted (and in accordance with the wonderfully simple but much maligned Gough) that the reviewing court personifies the reasonable person, ${ }^{80}$ and, unless it can be said that it is not possible for a reasonable person to hold the view expressed by the Court, it is difficult to see how its assessment of the reasonable person's state of mind could rightly be assailed.

One is comforted in this uncomfortable conclusion by the knowledge that the situation would be no less uncomfortable were one to adhere to the orthodox common law fiction. In fact, this fiction leads the Court into more troubled waters. However, it also depends on the question being asked. Is the question:

(a) 'Is this an apprehension that is capable of being held by a reasonable and fair-minded person?'; or

(b) 'Is this an apprehension that no reasonable and fair-minded person could possibly hold?'; or

(c) 'Is this an apprehension that would be held by all reasonable and fairminded persons?'

Obviously, the answer cannot be (c), otherwise almost every petition for recusal/disqualification on grounds of apprehended bias would be doomed to

77 Ibid.

78 [1993] AC 646, 670.

79 Compare Lord Clarke in AG of the Cayman Islands v Tibbetts [2010] UKPC 8, [6]: 'It is thus for the court to ascertain the circumstances. The court must approach the issues in two stages. First, it is for the court to find the facts on the balance of probabilities. It is then for the court to decide on the balance of probabilities whether, with knowledge of the facts so found, the putative observer would conclude that ....'

80 Compare Stanley Burnton LJ, in Virdi v Law Society [2010] EWCA Civ 100, [38]. 
failure. The answer is a combination of (a) and (b), as they are, in reality, two sides of the same coin. As has been seen earlier, the common law principle seeks to apply an objective test ${ }^{81}$ and speaks in terms of possibilities. ${ }^{82}$ Disqualification/recusal is dependent upon whether it is possible for a reasonable, informed observer to question the impartiality of the judge. ${ }^{83}$ According to the House of Lords in Lawal $v$ Northern Spirit Ltd, ${ }^{84}$ 'public perception of the possibility of unconscious bias is the key'. Doubts must be resolved in favour of recusal. ${ }^{85}$ All this is trite and requires no elaboration. However, the ECtHR observed in De Cubber v Belgium ${ }^{86}$ that

[T] he impartiality of the [impugned] court was capable of appearing to the applicant to be open to doubt. Although the Court itself has no reason to doubt the impartiality of the member of the judiciary who had conducted the preliminary investigation, it recognises, having regard to the various factors discussed above, that his presence on the bench provided grounds for some legitimate misgivings on the applicant's part.

Here the ECtHR decided on the basis of how the matter might appear to other parties, even though the Court itself had no misgivings. Had the EACJ applied a similar approach in Nyong'o, the outcome might (and arguably ought to) have been different. Apart from that, although Keiwua P did not himself feel compromised, the common law question is how the matter would appear to others, rather than how it appears to the impugned judge. It is impossible to state that no reasonable person could be apprehensive that a judge who was sitting in a case involving a party (governmental or otherwise) that had taken action against that judge in the recent past might possibly find it difficult to be impartial in respect of that party. It is also impossible to state that anyone who had such an apprehension could not possibly be reasonable. Thus, had it not been for the waiver, the orthodox common law approach may have required that Keiwua $\mathrm{P}$ recuse himself, and that the EACJ vacate the impugned 2006 decision in which he had participated. This is just another way of saying that the only way in which the EACJ could have rightly reached its eventual outcome in respect of the fair-minded observer was to have

81 Allsop J of the Federal Court of Australia described it as the judge's conduct being 'objectified' through the prism of what a fair-minded and informed observer would reasonably apprehend. See Nadh of $2001 v$ Minister for Immigration and Multicultural and Indigenous Affairs (2005) 214 ALR 264, [21].

82 See for example, $R v$ Gough, supra note 29, p. 670; Porter v Magill [2001] UKHL 67, [101]-[103]; Ebner v Official Trustee [2000] HCA 63, [7].

83 See for example, Ebner v Official Trustee, supra note 13, at [6]; Orange Ltd v Director of Telecoms (no. 2) [2004] 4 IR 159, 186; Johnson v Johnson, supra, at [11]; Porter v Magill, supra note 20; Lawal v Northern Spirit Limited [2003] UKHL 35, [21]; Liteky v US (1994) 127 L Ed 2d 474, 497.

84 Supra, at [14].

85 Locabail [1999] EWCA Civ 3004, [25]; Davidson v Scottish Ministers [2002] Scot CS 256, [16]; Hurst \& Devlin v State of Queensland [2004] FCA 427; In re Chevron U.S.A., Inc. (1997) $121 \mathrm{~F}$ 3d 163, 165 (5th Circ); In re Faulkner (1998) 856 F 2d 716, 721 (5th Circ).

86 (1984) 7 EHRR 236, [30]. 
followed the Gough principle that the reviewing Court personifies the reasonable person, and that it is therefore the view of the reviewing Court that matters.

\section{Jurisdiction}

The EACJ had started with a positive ruling on its jurisdiction to hear an application to set aside its own rulings on grounds of bias, relying on an inherent jurisdiction at common law and article 35 of the EAC Treaty. The Court clearly possesses the jurisdiction to vacate its own decision. The relevant provisions of article 35(3) of the EAC Treaty have already been noted above. ${ }^{87}$ Those provisions clearly mandate review in a variety of situations, and it was unnecessary for the Court to rely on a common law jurisdiction in that respect. The first specified ground for review (that is, emergence of new facts) would seem to apply to any situation in which a disqualifying factor is discovered after judgement has been delivered in a case. The last stated ground for review (that is, mistake, fraud, error on the face of the record or injustice) appears to be more far-reaching. In Christopher Mtikila v AG of Tanzania \& $\mathrm{Ors}^{88}$ the EACJ described that ground as being 'rather novel'. According to the Court, the injustice that is normally considered is

That which results from any of the four preceding grounds of review. But here it would appear that injustice stands out on its own and not as an accompaniment or a consequence of one of the four grounds for review. This provides a wider scope for review than is normally the case. $^{89}$

Such a wide scope, particularly, the term 'injustice', would arguably cover cases of disqualifying bias. Thus, it would appear that the EAC Treaty provisions confer the necessary jurisdiction to review (and if necessary vacate) earlier decisions. While the Court's jurisdiction to review its own decisions is clear, one area of potential difficulty is where there is a difference of opinion between the impugned judge and the rest of the Court as to whether the judge's recusal is required. The Court's view is that, 'subject to the judge whose recusal is sought giving his individual decision on the matter', the judges hearing the case have the duty to determine whether there are sufficient grounds for the impugned judge to recuse himself from further participation in the case. ${ }^{90}$ This seems to suggest that the judge's decision would prevail - a position that (if that is what the Court meant) would be consistent with the common law, but one that then questions the need for the rest of the Court to be involved at all.

87 Supra, note 41.

88 Application no. 8 of 2007, arising from EACJ Reference no. 2 of 2007, available at http://www.eacj.org/docs/judgements/EACJ_reference_No2_2007.pdf (accessed 13 July 2012)

89 At p. 5.

90 At p. 15 of its ruling. 


\section{The Recusal Procedure}

The manner in which the Nyong'o recusal application unfolded in the EACJ was problematic. The Attorney General of Kenya brought the application for two judges to disqualify themselves. The applicant then later 'and informally' made substantial alterations to the application in the course of the hearing. The alterations included withdrawal of the application in respect of one judge, and withdrawal of certain statements and parts of the application. While some of these twists and turns are understandable, there were other, more sinister forces at work, the first of which being the manner in which the application was made. A scheduling conference had been fixed for a certain date. On that date, just before the scheduling conference was due to start, in the Court's own words ${ }^{91}$

[T]he most unexpected happened. Kenya's Solicitor General ... called on the President of the Court in his chambers to inform him that unless he and Justice Kasanga Mulwa disqualified themselves from further hearing of the reference, he had instructions to file this application. He handed to him copy of the Notice of Motion duly signed and dated 19th January 2007 with the Supporting Affidavit... The President consulted the other members of the Court present. Needless to say, the judges were all extremely surprised by the move, considering that no indication whatsoever had been given prior to that day that the Attorney General of Kenya had any apprehension about the two judges being on the Coram for hearing the reference, a fact he knew before the 24th November 2006; and notwithstanding that the facts on which he based the application for recusal were within his knowledge years before the reference was filed in this Court.

The Court also noted that ${ }^{92}$

The applicant did not only file the response to the reference within the abridged time he had undertaken to the Court, but according to the information disclosed in his application, he was involved in a parallel process of amending the Treaty. We note that clearly the amendment is a direct reaction to the impugned ruling of the Court. In his response to the reference filed on $30^{\text {th }}$ December 2006, the applicant continues to protest the Court's jurisdiction, an issue that was already decided, but does not hint at, let alone raise, any objection to the sitting of any member of the Court on ground of any appearance or perception of bias. He chooses to do so only when the case is moving close to hearing and uses the opportunity to inform the Court through the affidavit of Dr. Wario that the amendments to the Treaty have been ratified by the Republic of Kenya and awaits [sic] ratification by the other two Partner States to come into force. 
The Court thus concluded that the application was brought 'more out of a desire to delay the hearing of the reference than a desire to ensure that the applicant receives a fair hearing' ${ }^{93}$ This was, according to the Court, an abuse of the court process.

This unusual set of circumstances ${ }^{94}$ unfortunately conspired to obfuscate some issues. While some of the surrounding circumstances are alarming and clearly undermine the Court, the procedural difficulties are understandable given the relative newness of the court and the absence of a prescribed procedure for initiating recusal motions therein. The Court commended the 'procedure practiced in the East African Partner States', which was similar to that advocated by the Constitutional Court of South Africa, namely that:

$[C]$ ounsel for the applicant seeks a meeting in chambers with the judge or judges in the presence of [the] opponent. The grounds for recusal are put to the judge who would be given an opportunity, if sought, to respond to them. In the event of recusal being refused by the judge the applicant would, if so advised, move the application in open court. ${ }^{95}$

While a difference of opinion between the impugned judge and the rest of the Court could unravel this procedure, it seems to have been followed in Nyong'o itself. Reference has already been made to the statement of the Court ${ }^{96}$ that Keiwua P had declined to recuse himself, that the Court agreed with his position, and that his response should be deemed to have been incorporated into the Court's own decision. So it is clear that Keiwua $\mathrm{P}$ had previously ruled on the matter (the format in which this previous ruling took place is not clear). When the Court heard the application addressed to it, Keiwua $\mathrm{P}$ seems to have participated fully in the proceedings. This is rather unfortunate, and may be contrasted with the situation in the Supreme Court of Canada in WewaykumIndian Band $v$ Canada, ${ }^{97}$ where the Court heard an application alleging that one of its Justices, Binnie $\mathrm{J}$, had been disqualified from participating in an earlier decision of the Court. Binnie $J$ recused himself from further participation in those proceedings, and the application proceeded in his absence. This, it is submitted, is the procedure that should have been followed in Nyong' $O$. The participation of a judge in proceedings arguing for his or her disqualification is objectionable, not least on the grounds that it arguably flies in the face of the rule against bias, as such a judge is clearly a party in the proceedings. This is one of the failings of the common law recusal jurisprudence.

93 At p. 23.

94 The rushed amendment to the Treaty was later held to contravene article 38(2) of the Treaty (acceptance of judgements of the Court by partner states). See East African Law Society and Others $v$ Attorney General of the Republic of Kenya and Others (Ref. No. 3 of 2007) [2008] EACJ 1 (1 September 2008).

95 The President of the Republic v South African Rugby Football Union [1999] ZACC 9; 1999 (4) SA 147; 1999 (7) BCLR 725, [50].

96 At p. 26.

97 [2003] 2 SCR 259; 2003 SCC 45. 


\section{CONCLUSIONS - THE ROAD TO A TREATY AMENDMENT?}

As the recusal jurisprudence of the EACJ takes shape, the Court has been able to rely appropriately on aspects of the common law principles on judicial bias. The common law principles are themselves largely consistent with globally recognised norms on fundamental justice. However, the common law clearly does not always have the right answers, and the EACJ's emerging recusal doctrine, as has been argued, has not successfully escaped the common law recusal quagmire. The common law is ill-equipped to resolve some of the jurisdictional issues, as has been seen in the preceding discussion. The waiver principle raises complex issues. While waiver is an established common law principle, its application in judicial bias cases in any court needs to be measured carefully - but in the context of a court that adjudicates between states, even greater care is needed. There is arguably a case for insisting on express waivers. The Court needs to earn the trust and confidence of the EAC partner states - and also of their citizens. Constructive waiver, except perhaps in the context of a clear attempt to abuse the Court's process, will not help to engender such trust and confidence-especially where the alleged waiver is disputed. Unfortunately, the restrictions on review of past decisions following discovery of new facts in article 35(3) of the EAC Treaty would serve as a formidable impediment to any bid to require express waiver. This issue would require discussion and negotiation within the EAC.

The Nyong'o case demonstrates inherent weaknesses in the EACJ's approach to the questions of judicial bias raised therein. The actual decision in respect of the application to vacate its earlier ruling is supportable on the grounds of article 35(3) of the EAC Treaty and possibly, but controversially, also on the principle of waiver. However, the Court's decision and process on the application for the judge to recuse himself from the current proceedings is problematic. The Court could have been faced with a major crisis in the event of differences of opinion between the impugned judge and the rest of the Court on the question whether the judge should recuse himself. Common law judges are famous for their pragmatism, and, no doubt, some compromise could be found were such a crisis to emerge. However, waiting for crisis situations to arise and then compromising or fudging the issues is being a hostage to fortune. With the accession to the EAC of Rwanda and Burundi, which have no significant common law heritage, there may well be no more room for common law fudges. What the EACJ needs is clear and express legislative authority to deal with these issues. It is therefore submitted that specific amendments to the EAC Treaty are required.

Interestingly, in the context of the appropriate amendments to the EAC Treaty, the beleaguered SADC Tribunal could come to the rescue. Article 9 of the SADC Protocol is pertinent. Article 9(1) prohibits a Member of the SADC Tribunal from activities that 'might interfere with the proper exercise of his or her judicial functions, impartiality or independence'. Article 9(2) provides examples of disqualifying activities that would prevent a Member of the Tribunal from adjudicating on a case. Article 9(3) then provides that 
Any dispute regarding the provisions of paragraphs 1 and 2 of this Article shall be resolved by a decision of the Tribunal sitting without the Member concerned.

Such a simple provision as article 9(3) would, if added to the EAC Treaty, provide an effective solution to the jurisdictional and procedural issues raised in this article, while however leaving the waiver controversies unresolved.

\section{A TEMPLATE FOR REFORM}

Much would be accomplished by the simple expedient of introducing into the EAC Treaty a provision similar in effect to article 9(3) of the SADC Protocol. However, I propose to go further than merely trying to address jurisdictional and process issues. It is not the purpose of this article to embark on an exercise in legislative drafting. For present purposes it suffices to indicate in general terms the kinds of provision that may, if added to article 35 of the EAC Treaty, be helpful in resolving the difficulties identified in this article and in formulating a better articulated recusal doctrine for the EACJ-one that it is hoped would assist in enhancing trust and confidence in the Court and its decision making processes. Below follow a number of proposed additions to article 35 of the EAC Treaty:

- A judge of the Court is disqualified from participating in any case or proceedings in which his or her impartiality may reasonably be questioned.

- The question whether the impartiality of a judge of the Court may reasonably be questioned shall be decided by the Court as a whole, without the participation of the judge(s) whose impartiality is at issue.

- A party who becomes aware of grounds for the disqualification of a judge in a case to which he or she is a party shall, if not willing to waive his or her right to object, file an application for the disqualification of the judge promptly.

- Parties in proceedings may waive their right to object to a disqualifying factor in respect of a judge, if such waiver is voluntary and unequivocal, and is preceded by full disclosure on the record by the judge of the basis for disqualification.

- Parties may not waive their right to object to a disqualifying factor if it relates to a judge being a party in the proceedings, or if it relates to a judge having a direct and substantial financial interest in the outcome of the proceedings.

- The Court shall, in dealing with any instance of waiver, consider whether there are any important public interests that militate against acceptance or application of the waiver.

- A party who wishes to apply for the disqualification of a judge under this Article shall lodge an application addressed to the 
Court, supported by an affidavit stating the facts upon which the application is based.

- A judge shall have the right to submit a statement to the Court in response to any application to disqualify him or her under these provisions, and shall take no further part in the proceedings in that case until the application is determined.

- If the Court decides that a judge's impartiality may reasonably be questioned, it shall issue a declaration that the judge is disqualified from hearing that case in accordance with this Article, and that judge shall take no further part in that case or any other proceedings that may arise from it.

- In any case in which a judge has been declared by the Court to be disqualified under these provisions, a temporary judge shall be appointed by the Summit as a substitute for that judge for the purposes of that case only.

- Any judge appointed as substitute for a disqualified judge under this Article shall be appointed from the same partner state as the disqualified judge.

- Where an application is made against more than one judge of the Court such that the Court would be unable to form a quorum without the participation of those judges, the Court, including the judges whose impartiality is at issue, shall sit to consider the application.

- A decision by the Court on a disqualification application shall be final and shall not be subject to review.

The suggestion for the application to be addressed to the Court as a whole rather than to the impugned judge is made for the following reasons - judges of the Court are already entitled under common law to recuse themselves in appropriate cases, on their own motion; in cases in which they do not recuse themselves, judges of the Court are already entitled to present themselves voluntarily for disqualification under article 26 of the EAC Treaty, subject to the decision of the presiding judge on the matter. Thus a judge who is aware of a disqualifying factor can already take appropriate action, either under common law, or under article 26 of the EAC Treaty. If a judge has not recused himself or herself and has not presented himself or herself for disqualification, then the reasonable conclusion is that this is because he or she is not aware of any factor that overrides the 'duty to sit'.

It is true that judges presented with recusal applications stating disqualifying facts of which they had not been previously aware can quickly agree to step down. Judges would also be able to correct quickly errors of fact disclosed in a recusal application directed to them personally. However, the same would apply in an application addressed to the Court rather than to the judge-and an application addressed to the Court avoids some of the difficulties referred to above. 